Horváth, Zs. \& Hollósy, V. G. (2019). The revision of Hungarian public service motivation (PSM) model. Central European Journal of Labour Law and Personnel Management, 2 (1), 17-28. doi: 10.33382/cejllpm.2019.02.02

\title{
THE REVISION OF HUNGARIAN PUBLIC SERVICE MOTIVATION (PSM) MODEL
}

\author{
Zsuzsanna Horváth ${ }^{1}$ - Gábor Hollósy-Vadász ${ }^{2}$ \\ ${ }^{1}$ Faculty of Commerce and Catering and Tourism, Budapest Business School, \\ Budapest, Hungary
}

2 Doctoral School of Public Administration Sciences, Faculty of Science of Public Governance and Administration, National University of Public Service, Budapest, Hungary

Received: 05. March 2019, Reviewed: 16. April 2019, Accepted 24. May 2019

\begin{abstract}
The Public Service Motivation Theory (PSM) turned up in the USA in the 90's, the European civil services applied the PSM concept later. Very few studies addressed the PSM in Hungarian context. One of those prepared a PSM model adapted to Hungarian public service. In this study, we develop and complete this model with job security as new variable. We use the PLS-SEM method to analyze the representative database of ISSP. According to our result, the job security can be adapted to the previous PSM model. We also identify the direct and indirect effects of job security on the other variables of the model. The results of this study can be adapted in human resource management of the Hungarian public administration. Therefore, we suggest the public policy makers to confirm the motivation and job security among the public sector employees.
\end{abstract}

Key words: Calling, organizational commitment, perceived social impact, public service motivation, work satisfaction

DOI: 10.33382/cejllpm.2019.02.02

JEL classification: J24, J28, J29

\section{Introduction}

The Hungarian public administration has a huge handicap to hire, retain and motivate the employees (Hazafi, 2017), because the private sector can provide better work conditions (Hazafi, 2015). That is why the Hungarian public sector can hire only professionals who can not find jobs in the private sector (Hazafi, 2015). The low level of motivation among public sector workers is a dysfunction of human resource management (Hazafi, 2017). Hazafi (2015) mentions that the three main resources of 
motivation in public sector are: 1) fair income, 2) stable carreer opportunity, 3) moral appreciation. On the one hand, Hajnal, Kádár and Kovács (2018) emphasize that Hungary has received a huge amount of support from the European Social Fund and the Norway Grants to develop its governance system. On the other hand, Hazafi (2017) mentions that the new career models and pay rise could not abolish the salary gap between the public and private sector. The average income in private sector was higher by $19 \%$ than in public sector in 2016 . Take into consideration the morale appreciation, Hollósy finds the labour representation of public service negative and no positive prestige is associated with working in public sector. The above mentioned factors reduce the competitiveness of the public sector and the motivation among the public sector employees. The aim of this study is to prepare and adapt a public service motivation model for the Hungarian public sector. The practical application of this model can help to optimize the motivation of the Hungarian public sector workers and increases the competitiveness of the Hungarian public sector.

The UNDP's study (2017) distinguishes intrinsic and extrinsic work motivation. The intrinsic motivation is an activity enjoyed by the individual. The work is carried out because the employee finds it interesting. The extrinsic motivation stimulates the employee to work hard and receive something for the work done. The above mentioned approach is not satisfactory to motivate the public sector workers, because it ignores the special needs of the employees and the special environment of public sector. The Public Service Motivation (PSM) is a relatively new research field. The motivation factors in the public sector can be different in terms of the national culture, the local economy, and the politics.

\section{Theoretical background}

PSM is an Anglo-Saxon theory turned up in North America in the 90's, also applied by the European public administration organizations (Mihalcioiu, 2011). Mihalcioiu (2011) mentions that PSM focuses on special motivation of public sector workers and also involves the main points of public management e.g. work satisfaction, organizational commitment and the incentive system. PSM is an individual predisposition how public sector employees react to the motivation tools applied in the public sector (Perry and Wise, 1990). Brewer and Selden (1998) added two aspects of the above mentioned definition. First, the PSM stimulates to serve the community. Second, PSM is relevant in the public sector The PSM concept was developed and completed in the 2000s. Vandenabeele (2007) says that PSM is a mix of attitudes, values, beliefs beyond the individual and organizational interest. These beliefs can modify the behaviour of public sector employees.

Mihalcioiu (2011) mentions that the main goal of NPM (New Public Management) was to rationalize the public sector, organize the resources more effectively and maximize the power, the budget and the public reputation. This approach cannot provide an explanation for the special motivation of public sector employees. This problem can be solved by PSM and its special dimensions. Perry and Wise (1990) identified three dimensions of PSM.

1. Rational: Whilst public servants behave in an altruistic way, they also want to increase their efficiency and importance. 
2. Norm-based: The main norm in public sphere is to serve the interest of society.

3. Affective: Public administration must provide safety for citizens based on basic human laws, thus applying the affective norm of patriotism of benevolence.

According to the study of Rainey and Steinbauer (1999), PSM can be manifested in general altruistic motivation to serve the interest of the local community, the interest of the state or the interest of the nation. The intrinsic motivation in connection with self-sacrifice can be a fundamental human feature and it can be as strong as the extrinsic motivation (e.g. received income).

We found numerous studies investigating the relationship between organizational commitment, job security, work satisfaction, perceived social impact, Calling, and PSM. We also use these variables in our model.

1. Bullock, Srich, and Rainey (2015) defined the organizational commitment. It is an individual strength that makes an employee to identify himself with the organization.

2. Bullock, Srich, and Rainey (2015) defined the perceived social impact that presents the impact of the work of public sector employee on the other people's live.

3. Calling is "a transcendent summons, experienced as originating beyond the self, to approach a particular life role in a manner oriented toward demonstrating or deriving a sense of purpose or meaningfulness and that holds other-oriented values and goals as primary sources of motivation" (Dik and Duffy, 2009. p. 427). Calling refers to being talented or passionate (Horváth, 2016; 2017a; 2017b; 2017c).

4. In the last decade, several studies have addressed the issue of work satisfaction (Westover and Taylor, 2009). According to the above cited study, work satisfaction is a positive emotional sate that originates from one's job experience.

5. Job security presents how secure an employee feels his/her job at the organization he/she is working for (Esser and Olsen, 2012). It is very important since the job of an employee generates the main source of income.

In Hungary, there is a scarcity of academic inquiry on PSM: only four relevant studies have been published up to date. One of them is a theoretical study investigating the adaption opportunities of PSM in Hungary (Hollósy and Szabó 2016). The second one investigates the relationship between PSM and job satisfaction in case of the local public service (Hollósy 2018). The third one prepares and adapts the Hungarian PSM model with PLS-SEM (see the method chapter) method (Horváth and Hollósy, 2018). Horváth and Hollósy (2018; 2019) use the representative database of ISSP 2015 and their model includes five variables: organizational commitment, work satisfaction, perceived social impact, motivation and Calling. The R2 of this model is $60 \%$, It means that public servants with high PSM, high organizational commitment, high Calling and high perception of the social impact are satisfied with their job. According to that study, the correlation between work satisfaction and organization commitment is over 0,9, which is especially high in social science. This result raises the question whether work satisfaction and organization commitment can be rejected or not. Calling has direct and indirect effects on work satisfaction. (We provide more details about direct and indirect effects in Method chapter.) The correlation between Calling and organizational 
commitment is also strong, so public sector workers with high Calling can get easily committed to public organizations.

In this study, we test and develop the model of Horváth and Hollósy (2018). We complete the model with job security as a new variable. Esser and Olsen (2011) define the job security as a variable that determines how secure the employees feel in their jobs. The job security "is a critical aspect of work quality because a person's work usually provides the main source of income and serves as an important basis for living conditions" (Esser and Olsen (2011, 443). Bullock, Hansen and Houston (2018) claim that most studies present that job security is more important in the public service than the private sector.

Hur and Perry (2016) report that scholars may focus on three aspects of job security:

1. The relationship between the objective job security and perceived job security.

2. The effect of job security on PSM among public administration workers.

3. Identifying the relationship between deinstitutionalization of job security and outcomes.

Based on the classification of Hur and Perry (2016) we cite some public administration studies that fit the second category. The job security is one of the main reasons that attracts public sector workers to public sector (Chen and Hsieh 2015). According to their study:

1. Job security correlates positively with PSM.

2. The pursuit of high pay correlates negatively with PSM.

3. The income satisfaction correlates positively with PSM.

4. The income satisfaction affects negatively the relationship between the pursuit of high pay and PSM.

Liu and Perry (2014) conducted a research in China to test the relationships between PSM and CCB (community citizenship behaviour), JS (job satisfaction), and OI (Organization identification). According to their results:

1. PSM correlates with the other variables. OI has a partial mediating effect on the relationship between PSM, CCB and JS.

2. Public service employees with high PSM are more compatible with the goals, missions and work environment of the public organizations than public service employees with low PSM.

3. PSM correlates negatively with organizational tenure. Furthermore, organizational tenure correlates negatively with OI, JS and CCB.

4. Although PSM and job security correlate positively with work attitudes (for example JS) and prosocial behaviour (for example CCB), PSM has stronger effect on work attitude and work behaviour than job security.

Ballart and Rico (2018) investigated the relationship between PSM and job security in Spain. The respondents study at a public university in Bacelona, so they have no work experience in public sector and avoid the socialization effects of public sector organizations. According their results:

1. In case of high level of attraction to public service and commitment to public values, the PSM can be compatible with job security.

2. Self-sacrificing students do not care about job security. 


\section{Material and methods}

Only few studies addressed the PSM concept in Hungary, therefore there is only one PSM concept adapted by the Hungarian public service, so this is an explorative research. In this study, we test and develop the model of Horváth and Hollósy (2018) as well as complete the model with job security as a new variable.

We tested two hypotheses:

1. $\mathbf{H ( 1 ) : ~ J o b ~ s e c u r i t y ~ a s ~ a ~ n e w ~ v a r i a b l e ~ c a n ~ b e ~ a d a p t e d ~ b y ~ t h e ~ o r i g i n a l ~ m o d e l ~}$ (Horváth and Hollósy 2018).

2. $\mathbf{H ( 2 ) : ~ J o b ~ s e c u r i t y ~ h a s ~ d i r e c t ~ a n d ~ i n d i r e c t ~ e f f e c t ~ o n ~ t h e ~ o t h e r ~ v a r i a b l e s ~ o f ~ t h e ~}$ model.

The Work Orientations 2015 module of the representative database of ISSP (International Social Survey Programme) was used as a basis for analysis, with delimitation of current employment. Therefore, Hungarian workers currently employed have been selected for further analysis $(n=564)$. The distribution of the gender of respondents is $(n=250)(44.3 \%)$ men and $(n=314)(55.7 \%)$ women. The youngest person is 27 years old and the oldest is 75 years old. The average age of the respondents is $(m=50.42$; $S D=10.837)$. $(n=141)(25 \%)$ and $(n=141)$ people worked in public sector. In further part of this study, we only analyse the responses of the public sector workers.

PLS -SEM (Partial Least Squares - Structural Equation Modeling) method was used to analyse the data. Path analysis is a series of regression analyses making it a predictive statistical method (Kovács and Bodnár 2016). Kazár (2014) distinguishes two types of structural equation models, the first one is the covariance-based structural equation model, the second one is the variance-based structural equation model. PLS-SEM is a variance-based structural equation model (Mitev and Kelemen 2017). Kovács and Bodnár (2016) mention that correlation coefficient presents the relationships between the variables in the model. This coefficient involves direct and indirect effects. Insignificant relationships between the variables are automatically ignored. The PLSSEM method is specifically adapted to detect and investigate an indirect effect between constructs and variables, making it a popular method is a number of disciplines (Kazár 2014). Kovács and Bodnár (2016) mention that PLS-SEM can run the factor analysis and the regression analysis simultaneously. The PLS-SEM does not require normal distribution and it is applicable for a sample with low number of respondents. Exogenous variables are the explanatory variables in the model. Endogenous variables can be explanatory variables but also target variables in the model. Regarding to the relationship between indicators and indirect variables, we can distinguish reflective and formative models. In reflective models, the indirect variable can be the reason and the effect of the indicator. In formative model, the indicator is the reason of the indirect variable. PLS-SEM can test the reflective and formative models.

The PLS-SEM method is useful when theoretical concepts cannot be measured directly, so the models based on them cannot be tested (Kovács,2015). The PLSSEM model includes two parts, the first one is the measurement, the second one is structural. The measurement part examines the indirect variables via direct variables. In order to assess the structural validity of the model, several in-build modules have been included in the software. The SRMR (Square Root Mean Square Residual) examines how theoretical concept fits to the empirical data (Mitev and Kelemen 
2017). The coefficient of SRMR is between 0 and 1 . The Cronbach-alfa represents the validity of convergence. AVE (Average variance extracted) tests the value of convergence. Both the value of Cronbach-alfa and AVE coefficient can be between 0 and 1 . The coefficient of Cronbach-alfa must be over 0,7 to accept the validity of the test. The coefficient of AVE must be over 0,5 to accept the validity of the test. Fornell and Larcker test is able to test the validity of discriminant. According to this test, the value of AVE must be over the squares of correlations between the constructions.

Results of the path analysis are presented in a diagram with arrows pointing from indirect variables to indirect dependent variables. Arrows can point from indirect variable to direct variables, or from indirect explanatory variables to indirect target variables. Indirect variables are marked with circles and direct variables with squares.

\section{Results and discussion}

Firstly, we tested the convergent and the discriminant validity (see Table 1 and Table 2). The convergent and discriminant validities are over the expected levels.

Table 1. The convergent validity

\begin{tabular}{|l|c|c|}
\hline Variable & Cronbach-alfa & AVE \\
\hline Calling & 1,000 & 1,000 \\
\hline Job security & 0,788 & 0,560 \\
\hline Organizational commitment & 0,790 & 0,585 \\
\hline Perceived social impact & 0,745 & 0,512 \\
\hline Work satisfaction & 0,851 & 0,757 \\
\hline
\end{tabular}

Source: own processing

Table 2. The discriminant validity

\begin{tabular}{|l|c|c|c|c|c|}
\hline & Calling & Job security & $\begin{array}{c}\text { Work } \\
\text { satisfaction }\end{array}$ & $\begin{array}{c}\text { Organizational } \\
\text { commitment }\end{array}$ & $\begin{array}{c}\text { Perceived } \\
\text { social impact }\end{array}$ \\
\hline Calling & 1,000 & & & & \\
\hline Job security & 0,447 & 0,749 & & & \\
\hline $\begin{array}{l}\text { Work } \\
\text { satisfaction }\end{array}$ & 0,373 & 0,449 & 0,870 & & \\
\hline $\begin{array}{l}\text { Organizational } \\
\text { commitment }\end{array}$ & 0,796 & 0,695 & 0,494 & 0,765 & \\
\hline $\begin{array}{l}\text { Perceived social } \\
\text { impact }\end{array}$ & 0,708 & 0,429 & 0,302 & 0,749 & 0,716 \\
\hline
\end{tabular}

Source: own processing 
We created a model (Figure 1) using the above mentioned variables. The thickness of arrows represents the strength of correlations.

Figure 1. The path analysis of Calling, organizational commitment, job security, work satisfaction and perceived social impact

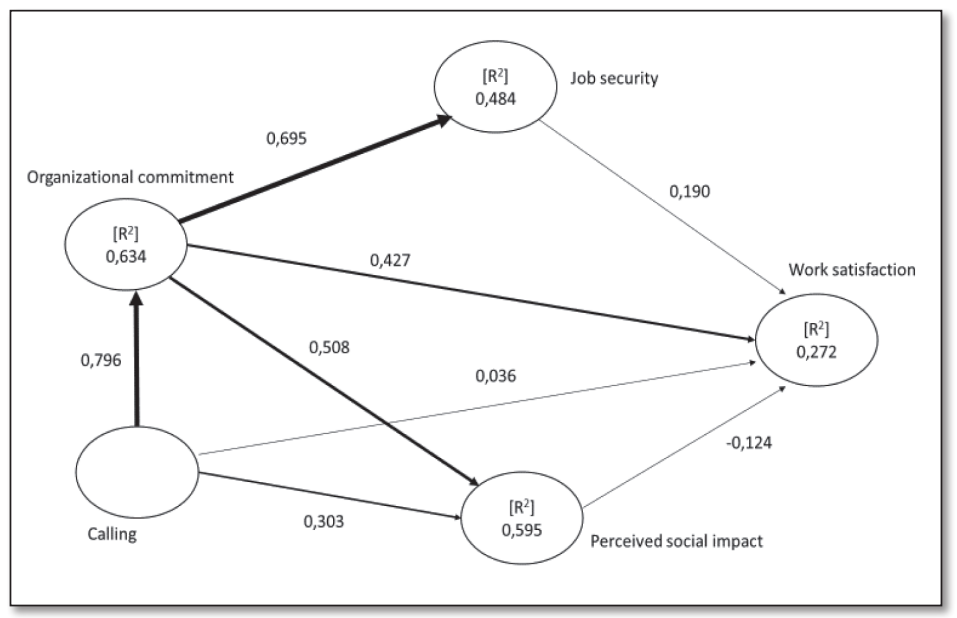

Source: own processing

The correlation is especially strong between Calling and organizational commitment; organizational commitment and job security. The correlation is moderately strong between the organizational commitment and perceived social impact. The correlation is 0,4 between work satisfaction and organizational commitment. Calling is an explanatory variable. Work satisfaction is a target variable. The other variables are explanatory and target variables as well. Calling has impact on job security via organizational commitment. Organizational commitment has direct effect on work satisfaction and on perceived social impact.

We use bootstrapping method to test the significance of paths between the variables. Bootstrapping analysis estimates variances, confidence intervals and other statistical attributes based on random samples extracted from an existing previous sample (Füstös, 2009). Table 3 presents the results of the bootstrapping method. 
Table 3. The results of bootstrapping

\begin{tabular}{|l|c|c|c|c|c|}
\hline $\begin{array}{l}\text { Test of couple of } \\
\text { factors }\end{array}$ & $\begin{array}{l}\text { Original } \\
\text { sample }\end{array}$ & Mean (M) & $\begin{array}{c}\text { Standard } \\
\text { Deviation } \\
\text { (SD) }\end{array}$ & T statistics & P value \\
\hline $\begin{array}{l}\text { Calling -> } \\
\text { Organizational } \\
\text { commitment }\end{array}$ & $0.796 * * *$ & 0.795 & 0.044 & 18.028 & 0.000 \\
\hline $\begin{array}{l}\text { Calling > Perceived } \\
\text { social impact }\end{array}$ & $0.303^{* *}$ & 0.305 & 0.151 & 2.010 & 0.045 \\
\hline $\begin{array}{l}\text { Calling -> Work } \\
\text { satisfaction }\end{array}$ & 0.036 & 0.067 & 0.910 & 0.040 & 0.968 \\
\hline $\begin{array}{l}\text { Job security -> Work } \\
\text { satisfaction }\end{array}$ & 0.190 & 0.192 & 1.071 & 0.177 & 0.860 \\
\hline $\begin{array}{l}\text { Organizational } \\
\text { commitment -> Job } \\
\text { security }\end{array}$ & $0.695 * * *$ & 0.700 & 0.077 & 9.091 & 0.000 \\
\hline $\begin{array}{l}\text { Organizational } \\
\text { commitment -> } \\
\text { Perceived social impact }\end{array}$ & $0.508 * *$ & 0.509 & 0.154 & 3.305 & 0.001 \\
\hline $\begin{array}{l}\text { Organizational } \\
\text { commitment }>\text { satisfaction }\end{array}$ & 0.427 & 0.416 & 2.374 & 0.180 & 0.857 \\
\hline $\begin{array}{l}\text { Perceived social impact } \\
\text {-> Work satisfaction }\end{array}$ & 0.124 & 0.150 & 0.951 & 0.131 & 0.896 \\
\hline SOurce: OWn processing & & & & & \\
\hline
\end{tabular}

The next step focused on the mediation analysis revealing the underlying indirect effects between the variables. The indirect effects analysis was conducted on all possible paths. Therefore, the effects of intermediate variables are unknown. The effects of intermediate variables are important because the groups differ alongside of these variables. These are called specific indirect effects. Table 4 presents our mediation analysis. VAF is an acronym for Variance Accounted For.

Table 4. The results of mediation analysis

\begin{tabular}{|l|c|c|c|c|c|}
\hline $\begin{array}{l}\text { Relationships between } \\
\text { indirect variables }\end{array}$ & $\begin{array}{c}\text { Total } \\
\text { indirect } \\
\text { effect }\end{array}$ & $\begin{array}{c}\text { Bootstrapping } \\
\text { significance }\end{array}$ & $\begin{array}{c}\text { Total } \\
\text { effect }\end{array}$ & $\begin{array}{c}\text { Bootstrapping } \\
\text { significance }\end{array}$ & VAF \% \\
\hline $\begin{array}{l}\text { Calling - } \\
\text { Organizational } \\
\text { commitment -> } \\
\text { Perceived social } \\
\text { impact }\end{array}$ & 0,403 & 2.847 & 0,705 & 10.854 & $57 \%$ \\
\hline $\begin{array}{l}\text { Calling -> } \\
\text { Organizational } \\
\text { commitment -> Job } \\
\text { security - W Work } \\
\text { satisfaction }\end{array}$ & 0,109 & 1.618 & 0,393 & 3.484 & $28 \%$ \\
\hline $\begin{array}{l}\text { Source: OWn processing } \\
\text { Sourcen }\end{array}$ & & & & \\
\hline
\end{tabular}


Only 141 public sector employees participated in this study, so limited interpretation of results can be provided. In this study we test and develop the PSM model of Horváth and Hollósy (2018). Our results suggest that job security as a new variable can be adapted to the model. Hypothesis 1 is approved. This result is supported by Chen and Hsieh (2015), who found that job security correlates positively with PSM. The model can explain $48 \%$ of job security. The organizational commitment correlates strongly to job security, so public sector workers with high organizational commitment believe their organization can provide stability and security. Calling does not have direct and indirect effect on job security. According to the mediation analysis, Calling has indirect effect on perceived social impact (VAF $=57 \%$ ) and on work satisfaction (VAF $=.28 \%$ ). Calling can indirectly modify how public sector employees evaluate the social impact of their work. In case of public service workers, this transcendent summons as primary source of motivation and can be manifested in the perceived social impact. So, Calling can get implemented to PSM researches. This is in connection to the study of Thompson and Christensen (2018) who mention that PSM and Calling together can offer a prolific research area to the scholars. Calling has indirect effect on work satisfaction via organizational commitment and job security. This result correlates to the study of Horváth and Hollósy (2018), where Calling has also indirect effect on work satisfaction.

According to the bootstrapping analysis, the work security has latent relationship only to organizational commitment. The work security can be adapted to the model, but its indirect effects are not remarkable. Since the work security correlates strongly to the organizational commitment, it indicates that a public sector worker with perception of a stable job becomes loyal to his or her organization. Calling has an indirect effect on organizational commitment and on perceived social impact. It means that Calling can modify the perception of public sector workers how relevant and essential they feel their work contributes to the public interest. This result is supported by the study of Markow and Klenke (2005) who find that Calling is a predictor of organizational commitment. The main finding of this study that Calling and job security can be added to the PSM concept. The organizational commitment has direct and indirect effect on the perceived social impact. The job security has direct and indirect effect on the perceived social impact. Our results do not confirm Hypothesis 2 because job security has direct and indirect effect on the organizational commitment and on perceived social impact, but job security does not have relationship to Calling. This PSM model can explain $63 \%$ of the organizational commitment. According to the model, those public sector employees are committed to their organizations who notice life goals, know how their work contributes to well-being of the society and they believe their jobs are secure.

Further studies should test and develop the original PSM model, what kind of variables can be adapted to the model and contribute to increase the motivation of public sector professionals.

\section{Conclusion}

Ideally, the highly motivated staff is the output of well functioning human resource departments. According to the study of Hazafi (2017), one of the main problems of the Hungarian human resources management in the public sector is the under motivated employee. The new career models and pay rise could not abolish the salary gap between the public and private sector (Hazafi, 2017). The moral reputation of public service is not positive (Hollósy under construction), so we need to find other method 
to motivate the public sector workers. PSM seems to be a good possibility to motivate these employees. This is the third empirical study that proves the validity of PSM in case of Hungary. However, this is the second study that prepares a valid PSM model for the Hungarian public sector. As we know, no Hungarian public institution uses or tests the PSM method. The reasons can be:

1. PSM method is not well known by managers in the public sector.

2. Implementing the PSM concept in the public sector has some direct and indirect effects on the human resource management including the process of hiring to the outplacement. The recruiters should check the motivation of candidates to serve the public interest. The HR professionals should educate the employees via trainings how their work influences the society and their work contributes to the well-being of the society. The managers in public sector should redesign the entire HR process.

3. Managers in the public sector are afraid how their staff will react to the redesigned function of HR departments.

Although the above mentioned difficulties, we suggest the managers to install the PSM model. As we have proved in this study, the PSM concept can successfully contribute to improve the motivation in the public sector.

The Hungarian public sector should adapt to the changing work environment in order to enhance competitiveness on labour market. Fazekas (2017) mentions that these changes have effect on the tasks and the competencies. The author reports that the relevance of non- cognitive competencies (e.g. motivation to serve the public interest, altruism) has increased in developed countries. The development of non-cognitive competencies is necessary not only in the private sector but also in public sector as well. On the other hand, the non-cognitive competencies can be developed in adulthood. Fazekas (2017) also mentions that organizations should employ emotionally stable and cooperating professionals who are open to new challenges. These organizations can protect their own employees from the displacement effect of new technologies. We suggest that public administration trough development of PSM can get two benefits. Firstly, the public administration organizations may protect their employees from displacement effect of new technologies. Secondly, public administration organizations can increase indirectly the perceived work satisfaction and job security among their employees.

\section{References}

1. Ballart, X., Rico, G. 2018. Public or nonprofit? Career preferences and dimensions of public service motivation. Public Administration, 96 (2), 404-420.

2. Brewer, G., Selden, S. C. 1998. Whistle blowers in the federal civil service: new evidence of the public service ethic. Journal of Public Administration Research and Theory, 8 (3), 413-439.

3. Bullock, J. B., Hansen, J., R., Houston D. 2018. Sector differences in employee's perceived importance of income and job security: Can these be found across the contexts of countries, cultures and occupations? International Public Management Journal, 21 (2), 243-271. 
4. Bullock, J. B., Stritch, J. M., Rainey, H. G. 2015. International Comparison of Public and Private Employees Work Motives, Attitudes, and Perceived Rewards. Public Administration Review, 75 (3), 479-489.

5. Chen, C. A., Hsieh C. W. 2015. Does Pursuing External Incentives Compromise Public Service Motivation? Comparing the effects of job security and high pay. Public Management Review, 17 (8), 1190-1213.

6. Dik, B., Duffy, R. D. 2009. Calling and Vocation at Work Definitions and Prospects for Research and Practice. The Counseling Psychologist, 37 (3), 424-450.

7. Esser, I., Olsen, K. 2012. Perceived Job Quality: Autonomy and Job Security within a Multi-Level Framework. European Sociological Review, 28 (4), 443-454.

8. Fazekas, K. 2017. Nem kognitív készségek kereslete és kínálata a munkaerőpiacon. Budapest: Magyar Tudományos Akadémia Közgazdaság- és Regionális Tudományi Kutatóközpont Közgazdaság-tudományi Intézete, 20.

9. Füstös, L. 2009. A sokváltozós adatelemzés módszerei. Budapest: MTA Szociológiai Kutatóintézete Társadalomtudományi Elemzések Akadémiai Múhelye TEAM), 640..

10. Hajnal, Gy., Kádár, K., Kovács, É. 2018. Government Capacity and CapacityBuilding in Hungary: A New Model in the Making? The NISPAcee Journal of Public Administration and Policy, 11 (1), 11 -39.

11. Hazafi, Z. 2015. Néhány gondolat a közigazgatás munkaerő-piaci versenyképességérôl. Hadtudomány, 25 (E. különszám) 12-20.

12. Hazafi, Z. 2017. A stratégiai munkaerő-tervezés és a HRM-fejlesztés szerepe a versenyképes közszolgálat utánpótlásának biztosításában. Pro Publico Bono Magyar Közigazgatás; A Nemzeti Közszolgálati Egyetem Közigazgatás-Tudományi Szakmai Folyóirata (2), 48-83.

13. Hollósy, V. G. 2018. Public Service Motivation (PSM) and Job Satisfaction in Case of Hungarian Local Public Service. AARMS, 17 (1) 23-30.

14. Hollósy, V. G., Szabó, Sz. 2016. A pszichológiai megközelítésú PSM paradigma jelentősége a magyar közszolgálatban. Hadtudományi Szemle, 9 (2) 163-174.

15. Horváth, Zs. 2016. Assessing Calling as a Predictor of Entrepreneurial Interest. Society and Economy. 38 (4) 513-535.

16. Horváth, Zs. 2017a. Entrepreneurial self-efficacy mediates career calling and entrepreneurial interest. Prace Naukowe / Uniwersytet Ekonomiczny w Katowicach. Challenges for marketing in 21st century. 71-84.

17. Horváth, Zs. 2017b. Recent Issues of Employability and Career Management. Opus et Educati, 4 (2) 207-216.

18. Horváth, Zs. 2017c. Exploration of active citizenship, entrepreneurial behaviour and calling in career. University of Southern Queensland. Sydney.

19. Horváth, Zs., Hollósy, V. G. 2018. Testing the Public Service Motivation and Calling in Hungary. Acta Oeconomica Universitatis Selye, 7 (2) 47-58.

20. Horváth, Zs., Hollósy, V. G. (2019): Közszolgálati motivációs modellek tesztelése útelemzéssel. Statisztikai Szemle, 97 (3), 269-287.

21. Hur, H., Perry, J. L. 2016. Evidence-Based Change in Public Job Security Policy: A Research Synthesis and Its Practical Implications. Public Personnel Management, 45 (3) 264-283.

22. Kazár, K. 2014. A PLS-útelemzés és alkalmazása egy márkaközösség pszichológiai érzetének vizsgálatára. Statisztikai Szemle, 92 (1) 33-52.

23. Kovács, A. 2015. Strukturális egyenletek modelljének alkalmazása a Közös Agrárpolitika 2013-as reformjának elemzésére. Statisztikai Szemle, 93 (8-9) 801822. 
24. Kovács, P., Bodnár, G. 2016. Az endogén fejlődés értelmezése vidéki térségekben PLS-útelemzés segítségével. Statisztikai Szemle, 94 (2) 143-161.

25. Liu, B., Perry, J., L. 2014. The Psychological Mechanisms of Public Service Motivation: A Two-Wave Examination. Review of Public Personnel Administration, 36 (1) 4-30.

26. Markow, F., Karin, K. 2005. The effects of personal meaning and Calling on organizational commitment: an empirical investigation of spiritual leadership. International Journal of Organizational Analysis, 13 (1) 8-27.

27. Mihalcioiu, R. M. (2011). Public service motivation. EIRP Proceedings, 6 834-838.

28. Mitev, A., Kelemen, E. A. 2017. Romkocsma mint bricolage: Élményközpontú szolgáltatásérték-teremtés a romkocsmákban. Turizmus Bulletin, 17 (1-2) 26-33.

29. Perry, J. L., Wise, L. B. (1990). The Motivational Bases of Public Service. Public Administration Review, 50 (3) 367-373.

30. Rainey, H., Steinbauer, P. 1999. Galloping Elephants: Developing Elements of a Theory of Effective Government Organizations. Journal of Public Administration Research and Theory, 9 (1) 1-32.

31. Thompson, J. A., Christensen, R. K. 2018. Bridging the Public Service Motivation and Calling Literatures. Public Administration Review, 78 (3) 444-456.

32. UNDP Global Centre for Public Service Excellence (GCPSE) 2017. The SDGs and New Public Passion. What really motivates the civil service? Singapore: UNDP GCSE Report.

33. Vandenabeele, W. 2007. Toward a public administration theory of public service motivation. Public Management Review, 9 (4) 545 - 556.

34. Westover, J. H., Taylor, J. 2010. International differences in job satisfaction. The effects of public service motivation, rewards and work relations. International Journal of Productivity and Performance Management, 59 (8) 811-828.

\section{Authors contact}

Zsuzsanna Horváth, PhD, associate professor, Budapest Business School, Faculty of Commerce and Catering and Tourism, Bedő street 9, 1112, Budapest Hungary. Email: zsenilia1@gmail.com

Authors' ORCID: https://orcid.org/0000-0002-8417-8994

Gábor Hollósy-Vadász, PhD student, National University of Public Service, Faculty of Science of Public Governance and Administration, Doctoral School of Public Administration Sciences, Rend street 11, 1028, Budapest Hungary, Email: hvadaszg@gmail.com Authors' ORCID: https://orcid.org/0000-0001-5555-4922 